\title{
COMPARATIVE REPELLENCY DURATION OF CITRONELLA OIL LOTION (Cymbopogon nardus L.) BETWEEN Culex sp. WITH Aedes sp. AS LYMPHATIC FILARIASIS VECTOR
}

\author{
Rita Tjokropranoto ${ }^{1} *$ Rosnaeni $^{2}$, Marshellia Setiawan ${ }^{3}$, Alvin Eliata Cahyono $^{3}$
}

\begin{abstract}
${ }^{1}$ Dept. Parasitology Medical Fac. of Maranatha Christian University, Jl. Prof. drg. Suria Sumantri, MPH no.65 Bandung 40164

2Dept Farmacology Medical Fac of Maranatha Christian University, Jl. Prof. drg. Suria Sumantri, MPH no.65 Bandung 40164

3Medical Fac of Maranatha Christian University Jl. Prof. drg. Suria Sumantri, MPH no.65 Bandung 40164
\end{abstract}

Submitted: $12-07-2013$

Revised: 15-09-2013

Accepted: $09-12-2013$

*Corresponding author

Rita Tjokropranoto

Email :

rita_tjokropranoto@yahoo.com

\begin{abstract}
Lymphatic filariasis is a mosquito borne disease, transmitted by mosquitoes such as Culex, Anopheles, Aedes, Mansonia. Filariasis infection resulting in disability. The important method to avoid being bitten from mosquitoes is by using a repellent. The purpose of this study were to compare repellency duration of citronella oil lotion against Culex sp. to Aedes sp. and to compare its repellency duration to $\mathrm{N}, \mathrm{N}-$ diethyl-m-toluamide (DEET). Laboratory experimental design was conducted at each of five men as subjects using five randomly treatments: $20 \%, 40 \%$ citronella oil lotion (COL), lotion base (negative control), $12.5 \%$ DEET lotion with one-day time lag. Repellency duration, since the forearm was inserted into the cage until first mosquito land, was assessed using female Culex sp. and Aedes sp, according to modification of Fradin and Day method. Repellency duration was analyzed using one-way ANOVA, Tukey HSD followed by paired t-test level of significance with $\alpha=0.05$ level of significance at $p<0.05$. There were highly significant differences $(p<0.01)$ between average repellency duration (minute) of $20 \%, 40 \%, 80 \% \mathrm{COL}$ against Culex sp. and 40\%, 80\% against Aedes sp. compared to $12.5 \%$ DEET. It was concluded that citronella oil lotion was more effective to Culex sp. than that of Aedes sp. Nevertheless the potency of citronella oil lotion was weaker than $12.5 \%$ DEET.
\end{abstract}

Key word: Iotion citronelle oil, Culex sp., Aedes sp., Filariasis

\section{INTRODUCTION}

Lymphatic filariasis, a mosquito-borne disease, is caused by filarial nematodes Wuchereria bancrofti, Brugia malayi, or Brugia timori (Stolk, 2005). People with the disease can suffer from permanent disabilities due to lymphedema and elephantiasis, all of these cause extensive morbidity, and they are a major economic burden within disease-endemic countries (Neglected Tropical Diseases, 2009).

Filariasis is transmitted by mosquitoes bite in tropical and subtropical regions (Stolk, 2005). Culex sp. is the major vector of Wuchereria bancrofti and Brugia malayi, whereas Aedes aegypti and Mansonia are vectors of $B$. malayi in the Pacific and Asia (Centers For Diseases Control and Prevention, 2010).

In 1997 The World Health Assembly called for the Global Elimination of lymphatic filariasis as a public health problem. The most common method of vector control is residual spraying of insecticides, but majority of the chemical pesticides are harmful to human and animals. These insecticides are spreading toxic effects and are not easily degradable (Samidurai, et al., 2009). Recent studies stimulated the research of natural insecticides of plant derived which are environmentally safe, target specific, degradable and are used as insecticides for killing adult mosquitoes or as a repellents for protection mosquitoes bites (Motta et al., 2003; Samidurai et al., 2009).

The mosquitoes repellent is a substance applied to skin, clothing, or other surfaces which hold up mosquitoes from landing on that surface (Patel et al., 2012) .

Insect repellents can be divided into 2 categories such as synthetic chemicals and plant-derived essential oils. The most common mosquitoes repellent available on the market contain DEET called N,N-diethyl-3methylbenzamide (DEET) (Fradin and Day, 
2002), is the basically synthetic compound which shown excellent repellency against mosquitoes (Tawatsin et al., 2001) but have adverse effect to human and environment. The harmful to human for example irritation of skin erithema, pruritus. Accordingly, natural repellents with minimal side effect are required (BPOM, 2009). The natural repellents from plants derived such as Cymbopogon nardus $\mathrm{L}$. contains essential oil called Oleum Citronella which majority consist of citronellal, geraniol, citronellol, citral, $\alpha$ pinene and limonene are effective at the dose that of DEET. These substances work by interferring mosquitoes olfactory receptor hence discourage mosquito to bite (US.EPA, 2009; Maia, and Moore, 2011). Citronella oil is usually used by direct lubricated to the skin without adding the vehiculum. The study notify protection of citronella oil against Culex quinquefasciatus for 100 minute after topical applying citronella oil (Carrol, et al., 2006.; Maia and Moore, 2011).

Lotion is a suspension, solution or emulsion that can be diluted and usefull as topical drug, easily absorbed, and spread on to skin, so that has duration of action longer than that of atsiri oil (Ansel, 1989). In addition lotion was mixtures containing repellent dissolved in or diluted with alcohol (Patel et al., 2012).

The purpose of this study are to compare repellency duration of citronella oil lotion against Culex sp. to Aedes sp. and to compare repellency duration of citronella oil lotion repellent to N,N-diethyl-m-toluamide (DEET) against Culex sp. and Aedes sp.

\section{MATERIAL AND METHODS}

Research design is laboratory experimental. Repellency duration of citronella oil lotion was examined by modification of Fradin and Day method, with cross over design. Five men volunteers with no allergies to citronella oil and DEET, have signed the informed consent, they received five treatments $20 \%, 40 \%, 80 \%$ citronella oil lotion, $12.5 \%$ DEET, negative control with lapse of one day, the experimental animals were female Culex sp, Aedes sp. mosquitoes second generation that were between 7-24 days old were placed into laboratory test cage. Measured data was mean duration in minutes obtained since first time inserting forearm into the laboratory test cage until the first mosquito landing on to the forearm of subjects/volunteers.

Research materials were materials for making basic lotion such as cetaceum, cera alba, paraffin liquid, and natrii tetraborax, aquadest, citronella oil product from PT "D", repellent "X" which contains $12.5 \%$ DEET.

Laboratory cage with the dimension of $35 \mathrm{~cm} \times 35 \mathrm{~cm} \times 35 \mathrm{~cm}$, tool for catching mosquito, stopwatch digital, gram scale, measuring glass, pipette, vaporizer cup, water bath, stove, mortar, stamper, and stir bar.

\section{Methods}

Empty laboratory test cage with the dimension of $35 \mathrm{~cm} \times 35 \mathrm{~cm} \times 35 \mathrm{~cm}$ were prepared; Female Culex sp. mosquitoes unfed for $24 \mathrm{~h}$; Ten mosquitoes were put in the laboratory test cage. The volunteers/subjects being applied to 5 randomized treatments. Forearms of volunteers were applied with $1 \mathrm{~mL}$ citronella oil lotion from the elbow to the fingertips. Subsequently, the forearm were put into the laboratory test cage using modification of Fradin and Day method (Figure 1). Mean duration (minute) was determined since forearms were put into laboratory test cage until the first time mosquito landed on to forearm for 2-5 seconds. The forearm of subjects was washed with an unscented soap prior each subsequent application of repellents until clean and dry. Female mosquitoes Culex sp. and Aedes sp. that have been used were collected into one closed container for destroying. The experiments were randomized repeated for group treated by citronella oil lotion with the concentration of $20 \%, 40 \%$, $80 \%$, and positive control $(12.5 \%$ DEET lotion). Documentation and tabulations were made for a duration time (minute), determined since forearm inserted into laboratory test cage until the first time a mosquito landing on to the forearm for 2-5 seconds.

\section{Statistical analysis}

One way analysis of variance (ANAVA) followed by Tukey's HSD tests was used to compare the mean duration time for the repellence with $\alpha=0.05$.

$P$ value of less than 0.05 was considered to indicate statistical significance. Followed by 


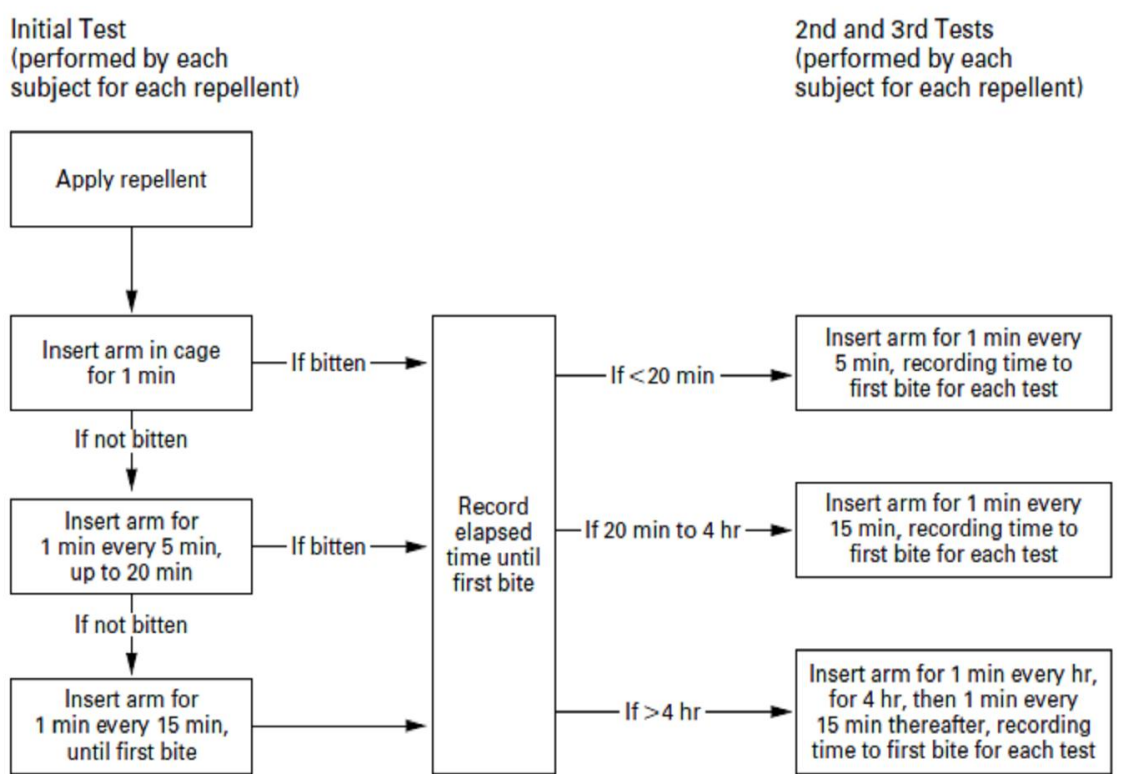

Figure 1. Study design by Fradin and Day method (Fradin and Day, 2002)

Table I. Result of Tukey HSD test of mean duration time of reppllency effectivity of citronella oil lotion to Culex sp.

\begin{tabular}{|c|c|c|c|c|c|c|}
\hline \multirow{2}{*}{\multicolumn{2}{|c|}{ Group treatment $(n=5)$}} & \multicolumn{5}{|c|}{ Duration of reppllency effectivity (minute) } \\
\hline & & $\begin{array}{c}I \\
56.68\end{array}$ & $\begin{array}{c}\text { II } \\
92.02\end{array}$ & $\begin{array}{c}\text { III } \\
216.50\end{array}$ & $\begin{array}{c}\text { IV } \\
23.11\end{array}$ & $\begin{array}{c}\mathrm{V} \\
290.12\end{array}$ \\
\hline Group I & 56.68 & & $* *$ & $* *$ & $* *$ & $* *$ \\
\hline Group II & 92.02 & & & ** & ** & $* *$ \\
\hline Group III & 216.50 & & & & ** & $* *$ \\
\hline Group IV & 23.11 & & & & & $* *$ \\
\hline Group V & 290.12 & & & & & \\
\hline
\end{tabular}

Note :

Group I: Citronella Oil Lotion 20\%; Group. II: Citronella Oil Lotion 40\%; Group. III: Citronella Oil Lotion $80 \%$; Group. IV: Negative Control (basis lotion); Group. V: Positive control (12,5\% DEET lotion); **: Very Significant $(p<0,01)$

Table II : Result of Tukey HSD test of mean duration time of reppllency effectivity citronella oil lotion to Aedes sp.

\begin{tabular}{|c|c|c|c|c|c|c|}
\hline \multicolumn{2}{|c|}{$\begin{array}{c}\text { Group Treatment } \\
\qquad(\mathrm{n}=5)\end{array}$} & $\begin{array}{c}I \\
8.95\end{array}$ & $\begin{array}{c}\text { II } \\
16.23\end{array}$ & $\begin{array}{c}\text { III } \\
34.02\end{array}$ & $\begin{array}{c}\mathrm{IV} \\
0.30\end{array}$ & $\begin{array}{c}\mathrm{V} \\
82.36\end{array}$ \\
\hline Group I & 8.95 & & $\mathrm{NS}(p=0.15)$ & $* *$ & $\mathrm{NS}(p=0.15)$ & $* *$ \\
\hline Group II & 16.23 & & & $* *$ & $* *$ & ** \\
\hline Group III & 34.02 & & & & ** & $* *$ \\
\hline Group IV & 0.30 & & & & & $* *$ \\
\hline Group V & 82.36 & & & & & \\
\hline
\end{tabular}

Note:

Group I : Citronella Oil Lotion 20\%; Group II : Citronella Oil Lotion 40\%; Group III: Citronella Oil Lotion 80\%; Group IV : Negative Control (basis lotion); Group V: Positive control (12,5\% DEET lotion); **: Very Significant $(p<0,01)$; NS : Not Significant 
Table III : Paired t-test comparing mean duration time of reppllency effectivity citronella oil lotion at concentration of 20\%,40\%,80\% between Culex sp. and Aedes sp.

\begin{tabular}{cccccc}
\hline & & Mean & N & Std. Deviation & Std. Error Mean \\
\hline Pair 1 & AEDES20 & 8.9540 & 5 & 3.20573 & 1.43365 \\
& CULEX20 & 56.6760 & 5 & 8.00610 & 3.58044 \\
Pair 2 & AEDES40 & 16.2300 & 5 & 3.38934 & 1.51576 \\
& CULEX40 & 92.0200 & 5 & 7.12618 & 3.18692 \\
Pair 3 & AEDES80 & 34.0180 & 5 & 3.55692 & 1.59070 \\
& CULEX80 & 216.4960 & 5 & 7.88657 & 3.52698 \\
\hline
\end{tabular}

Table IV. Paired t-test comparing reppllency effectivity of citronella oil lotion between Culex sp. and Aedes sp.

\begin{tabular}{|c|c|c|c|c|c|c|c|c|c|}
\hline \multicolumn{10}{|c|}{ Paired Differences } \\
\hline & & \multirow[b]{3}{*}{ Mean } & \multirow{3}{*}{$\begin{array}{c}\text { Std. } \\
\text { Deviation }\end{array}$} & \multirow{3}{*}{$\begin{array}{l}\text { Std. } \\
\text { Error } \\
\text { Mean }\end{array}$} & \multicolumn{2}{|c|}{ 95\% Confidence } & \multirow[b]{3}{*}{$\mathrm{t}$} & \multirow[b]{3}{*}{ df } & \multirow{3}{*}{$\begin{array}{l}\text { Sig. (2- } \\
\text { tailed) }\end{array}$} \\
\hline & & & & & $\begin{array}{r}\text { Interva } \\
\text { Diffe }\end{array}$ & & & & \\
\hline & & & & & Lower & Upper & & & \\
\hline $\begin{array}{c}\text { Pair } \\
1\end{array}$ & $\begin{array}{l}\text { AEDES20 - } \\
\text { CULEX20 }\end{array}$ & -47.7220 & 6.94545 & 3.10610 & -56.3459 & -39.0981 & $\begin{array}{c}- \\
15.364\end{array}$ & 4 & .000 \\
\hline $\begin{array}{c}\text { Pair } \\
2\end{array}$ & $\begin{array}{l}\text { AEDES40 - } \\
\text { CULEX40 }\end{array}$ & -75.7900 & 9.63494 & 4.30888 & -87.7534 & -63.8266 & $\begin{array}{c}- \\
17.589\end{array}$ & 4 & .000 \\
\hline $\begin{array}{c}\text { Pair } \\
3\end{array}$ & $\begin{array}{l}\text { AEDES80 - } \\
\text { CULEX80 }\end{array}$ & $\begin{array}{c}- \\
182.4780\end{array}$ & 6.47632 & 2.89630 & 190.5194 & $\begin{array}{c}- \\
174.4366\end{array}$ & $\begin{array}{c}- \\
63.004\end{array}$ & 4 & .000 \\
\hline
\end{tabular}

Computer software was applied to determined, paired t-test of the mean duration time of reppllency effectivity for each concentration of citronella oil lotion $20 \%, 40 \%, 80 \%$ between Culex sp. and Aedes sp. with $\alpha=0.05$. P value of less than 0.05 was considered to indicate statistical significance.

\section{RESULT AND DISCUSSION}

The result of Tukey HSD Test Mean Duration Time reppllency effectivity of Citronella Oil Lotion of $20 \%, 40 \%, 80 \%$ were 56.68', 92.02', 216.50' minutes which were significance difference to that of $(p<0.01)$ $12.5 \%$ DEET that was 23.11 min against Culex sp. (Table I). This result due to DEET-sensitive olfactory neurons found in the antenna and maxillary palpi of Culex quinquefasciatus (Kongkaew et al., 2011).

The result of Tukey HSD of Mean Duration Time Effectiveness group of Citronella oil lotion $40 \%, 80 \%$ were obtained 16.23 ', 34.02 minutes which were very significance difference to that of $(p<0.01)$
DEET 12.5\% (82.36 minutes) as positive control group against Aedes sp (Table II).

The study showed that repellency effectiveness of citronella oil lotion of $20 \%$, $40 \%, 80 \%$ were weaker than that of DEET $12.5 \%$ against Culex sp. and Aedes sp., migth due to weight molecule of DEET (191.26) was higher than citronellal (154.24) and geraniol (154.24) (Hasni et al., 2007). Lotion was chosen, in order to obtain duration repellence longer and increase drug absorption because lotion was easily spread at the surface of the skin. In addition, vanillin could prolong the repellency of citronella oil and prolong protection time against Ae. aegypti, because vanillin that act as a barrier water vapour could delay evaporation (Ansel, 1989; Tawatsin, et al., 2001).

Paired t-test comparing mean duration time citronella oil lotion of each concentration specifically 20\% between Culex sp. and Aedes sp. 56.67' and $8.95 \mathrm{~min}, 40 \%$ between Culex sp. and Aedes sp. was 92.02 ' and $16.23 \mathrm{~min}, 80 \%$ between Culex sp. and Aedes sp. was 216.50 and 34.02 minutes were significant $\mathrm{p}$ value $<0.05$ 
(Table III and IV). This research illustrated that percentage on repellency properties on the application of citronella oil after $4 \mathrm{~h}$ were 94.4\%(4.5h), 76.9\%(5h), 62.5\%(5.5h), 60\%(6h) against Aedes sp. in contrast to Culex sp. repellency percentage that after application for $4 \mathrm{~h}$ was still the same it was $(100 \%$ ) (Tawatsin $e t$ al., 2001)

\section{CONCLUSION}

Citronella oil lotion has more effective repellency to Culex sp. than Aedes sp. but weaker potency than that of $12.5 \%$ DEET.

\section{ACKNOWLEDGEMENTS}

The authors thank to Department Parasitology Medical Faculty of Maranatha Christian University for supportng and providing the facilities.

\section{REFERENCES}

Ansel HC, 1989, Sistem pemberian obat melalui kulit, salep, krim, lotion dan preparat lain. Dalam: Farida Ibrahim, editor. Pengantar bentuk sediaan farmasi. Edisi 4. Jakarta: Penerbit Universitas Indonesia (UI-Press); h.490-494, 513, 9-21.

Badan Pengawas Obat dan Makanan. Bahaya deet pada insect - repellent. 2010 [cited January $\left.6^{\text {th }}, 2012\right]$. Available from : http://www.pom.go.id/public/siker/des c/produk/BahayaDEET padaInsect. pdf.

Carroll SP., Loye J. Pmd, 2006, A registered botanical mosquito repellent with deetlike efficacy. J Am Mosq Contr. Assoc.; 22 : 507-514.

Center for Disease Control and Prevention. Mosquito-borne diseases. 2010 [cited December $8^{\text {th }}$, 2011]. Available from: http://www.cdc.gov/ncidod/diseases/li st_mosquitoborne.htm.

Fradin MS, Day JF, 2002, Comparative efficacy of insect repellents against mosquito bites. N Engl J Med.; 347(1): 13-18.
Kongkaew C., Sakunrag I., Chaiyakunapruk N., Tawatsin A., 2011, Effectiveness of citronella preparations in preventing mosquito bites: systematic review of controlled laboratory experimental studies.Trop Med Int Health.16 : 802-10.

Maia MF., Moore SJ., 2011, Plant-based insect repellents: a review of their efficacy, development and testing. Malaria J.; 10 (suppl.1) : 1-14

Motta S, Monti M, 2003, Insect repellents. In Katsambas AD, Lotti TM, editors. European handbook of dermatological treatments. $2^{\text {nd }}$ ed. Verlag : Springer; pp.747-750.

Patel, E.K., Gupta, A., and Oswal, RJ, 2012, A review on: mosquito repellent Methods, Int. J. Pharm. Chem. Bio. Sci. Vol. 2(3), pp:310-317

Pusphanathan, T., Jebanesan, A and Govindarajan, M, 2006, Larvicidal, ovicidal and repellent activities of Cymbopogan citratus Stapf (Graminae) essential oil against the filarial mosquito Culex quinquefasciatus (Say) (Diptera : Culicidae), Trop.Biomed. 23(2): 208-212.

Samidurai. K., Jebanesan. A., Saravanakumar. A., Govindarajan. M and Pushpanathan.T, 2009, Larvicidal, ovicidal and repellent activities of Pemphis acidula Forst.(Lythraceae) against filarial and dengue vector mosquitoes.Ac. J.Entomol. 2 (2): 62-66.

Stock, W, 2005, Lymphatic filariasis, transmission, treatment, elimination, thesis University Erasmus Rotterdam .

Tawatsin A., Wratten SD., Scott RR., Thavara U, and Techadamrongsin Y, 2001, Repellency of volatile oil from plants against three mosquito vectors, $J$. Vector. Ecol. 26(1): 76-82.

United States Environmental Protection Agency. Active ingredients found in insect repellents. 2009 [cited August 13 ${ }^{\text {th }}$, 2012]. Available from: http://www. epa.gov/pesticides/health/mosquitoes/a i_insectrp.htm. 